\title{
Are patients with non-ST elevation myocardial infarction undertreated?
}

\author{
Saman Rasoul ${ }^{1}$, Jan Paul Ottervanger ${ }^{1}$, Jan-Henk E Dambrink ${ }^{1}$, Menko- \\ Jan de Boer ${ }^{1}$, Jan CA Hoorntje ${ }^{1}$, AT Marcel Gosselink ${ }^{1}$, Felix Zijlstra ${ }^{2}$, \\ Harry Suryapranata ${ }^{1}$ and Arnoud WJ van't Hof*1
}

\begin{abstract}
Address: ${ }^{1}$ Isala Klinieken, Dept of Cardiology, Zwolle, The Netherlands and ${ }^{2}$ University Medical Center Groningen, University of Groningen, The Netherlands

Email: Saman Rasoul - s.rasoul@isala.nl; Jan Paul Ottervanger - j.p.ottervanger@isala.nl; Jan-Henk E Dambrink - j.h.e.dambrink@isala.nl; Menko-Jan de Boer - m.j.de.boer@isala.nl; Jan CA Hoorntje - j.c.a.hoorntje@isala.nl; AT Marcel Gosselink - a.t.m.gosselink@isala.nl; Felix Zijlstra - f.zijlstra@thorax.umcg.nl; Harry Suryapranata - h.suryapranata@isala.nl; Arnoud WJ van't Hof* - v.r.c.derks@isala.nl

* Corresponding author
\end{abstract}

Published: 5 March 2007

BMC Cardiovascular Disorders 2007, 7:8 doi:10.1 186/147|-226I-7-8

This article is available from: http://www.biomedcentral.com/|47I-226I/7/8

(C) 2007 Rasoul et al; licensee BioMed Central Ltd.

This is an Open Access article distributed under the terms of the Creative Commons Attribution License (http://creativecommons.org/licenses/by/2.0), which permits unrestricted use, distribution, and reproduction in any medium, provided the original work is properly cited.
Received: 31 October 2006

Accepted: 5 March 2007

\begin{abstract}
Background: The worse prognosis in patients without ST-elevation (non-STEMI) as compared to ST-elevation myocardial infarction (STEMI), may be due to treatment differences. We aimed to evaluate the differences in characteristics, treatment and outcome in patients with non-STEMI versus STEMI in an unselected patient population.
\end{abstract}

Methods: Individual patient data from all patients in our hospital with a discharge diagnosis of MI between Jan $200 \mathrm{I}$ and Jan 2002 were evaluated. Follow-up data were obtained until December 2004. Patients were categorized according to the presenting electrocardiogram into non-STEMI or STEMI.

Results: A total of 824 patients were discharged with a diagnosis of MI, $29 \%$ with non-STEMI and $71 \%$ with STEMI. Patients with non-STEMI were significantly older and had a higher cardiovascular risk profile. They underwent less frequently coronary angiography and revascularization and received less often clopidogrel and ACE-inhibitor on discharge. Long-term mortality was significantly higher in the non-STEMI patients as compared to STEMI patients, $20 \%$ vs. $12 \%, \mathrm{p}=$ 0.006 , respectively. However, multivariate analysis showed that age, diabetes, hypertension and no reperfusion therapy (but not non-STEMI presentation) were independent and significant predictors of long-term mortality.

Conclusion: In an unselected cohort of patients discharged with $\mathrm{MI}$, there were significant differences in baseline characteristics, and (invasive) treatment between STEMI and non-STEMI. Long-term mortality was also different, but this was due to differences in baseline characteristics and treatment. More aggressive treatment may improve outcome in non-STEMI patients. 


\section{Background}

Myocardial infarction (MI) is usually categorized into non-ST-elevation myocardial infarction (non-STEMI) and ST-elevation myocardial infarction (STEMI). Patients with STEMI should be treated immediately with reperfusion therapy by either percutaneous coronary intervention (PCI) or thrombolysis, if admitted within $12 \mathrm{~h}$ of symptom onset [1-4]. Patients with non-STEMI should be stabilized medically and high-risk patients should be scheduled for an early (within days) interventional strategy $[5,6]$.

A previous study has shown that in unselected patients, mortality was significantly higher in the non-STEMI as compared to STEMI patients [7]. However, in that study coronary angiography was only performed in $52 \%$, only $70 \%$ of the eligible STEMI patients were treated with reperfusion therapy and no information was available with regard to the type of reperfusion therapy. The purpose of our study was to evaluate the baseline characteristics, treatment and prognosis in an unselected consecutive cohort of non-STEMI versus STEMI in a single high-volume centre.

\section{Methods}

Population

From January 2001 to January 2002, individual patient data from all patients with the discharge diagnosis of acute myocardial infarction at the Isala klinieken (Zwolle, The Netherlands) were recorded. To avoid double inclusion of patients, only the first admission for MI during the study period was used.

Non-STEMI patients consisted of only patients admitted to our center, however, STEMI patients included also those referred and those diagnosed by paramedics in the ambulance and transported directly to our center.

According to the presenting ECG, patients were categorized as non-STEMI or STEMI. Patients were diagnosed with non-STEMI if they had ischemic chest pain classified as Braunwald class 3 and the presence of at least 1 of the following criteria: (new) ST depression of more than 1 $\mathrm{mm}$ in at least 2 ECG leads or a positive biomarker (Cardiac Troponin $\mathrm{T}>0.05 \mu \mathrm{g} / \mathrm{L}$, or CK-MB elevation more than upper limit of normal). STEMI was defined as chest pain of $>30$ minutes' duration and ECG changes with ST segment elevation of $>2 \mathrm{~mm}$ in at least 2 precordial and $>1 \mathrm{~mm}$ in the limb leads.

\section{Data collection and follow-up}

We collected the following variables from the patient files: age, gender, history of hypertension, diabetes, hyperlipidemia, smoking, previous myocardial infarction and discharge medication. Follow-up information was obtained from the patient's general physician or by direct telephone interview with the patient.

\section{Ethics}

The investigation conforms with the principles outlined in the Declaration of Helsinki (Br Med J 1964, ii: 177). The study was approved by the Committee on Research Ethics of the Isala Klinieken, Zwolle.

\section{Statistical analysis}

Statistical analysis was performed with the Statistical Package for the Social Sciences (SPSS Inc., Chicago, IL, USA) version 12.0.1. Continuous data were expressed as mean \pm standard deviation of mean and categorical data as percentage, unless otherwise denoted. The analysis of variance and the chi-square test were appropriately used for continuous and categorical variables respectively. Cox proportional hazard regression procedure was performed to estimate the hazard ratio of mortality of the findings. Significant variables analyzed are reported with their respective Hazard ratio (HR) and 95\% confidence intervals (CI). For all analyses, statistical significance was assumed when the two tailed probability value was < 0.05 .

\section{Results}

During the study period, 824 patients were discharged with a diagnosis of MI and categorized as non-STEMI 29\% $(\mathrm{N}=241)$ and STEMI $71 \%(\mathrm{~N}=583)$.

\section{Baseline characteristics}

Baseline characteristics are summarized in Table 1. Patients with non-STEMI were significantly older, more often female, had more often hypertension and a history of previous myocardial infarction.

\section{Treatment}

Cardiac catheterization and percutaneous coronary intervention (PCI) were significantly less often performed in non-STEMI patients (Table 2). Coronary artery bypass grafting (CABG) was performed more often in the nonSTEMI patients, $17 \%$ vs. $3 \%, \mathrm{p}<0.001$. At discharge, nonSTEMI patients less frequently received clopidogrel, ACEinhibitors or a statin than STEMI patients. Nitrates and calcium channel blockers were prescribed more often in the non-STEMI patients. Aspirin and beta blockers were prescribed equally in both groups (Table 3 ).

\section{Outcome}

At 3 year follow up, mortality was $20 \%$ in the non-STEMI and $12 \%$ in the STEMI patients, $\mathrm{p}=0.006$ (Figure 1). Univariate predictors of mortality in the non-STEMI patients were age, diabetes, previous myocardial infarction and not performing CAG (Table 4). The excess mortality could not be attributed to the higher CABG rate in the non- 
Table I: Baseline

\begin{tabular}{|c|c|c|c|}
\hline Variable & $\begin{array}{l}\text { STEMI } \\
(N=583)\end{array}$ & $\begin{array}{l}\text { non-STEMI } \\
(\mathrm{N}=24 \mathrm{I})\end{array}$ & $P$-value \\
\hline Age, Y, Mean \pm SD & $63 \pm 12$ & $67 \pm 12$ & $<0.001$ \\
\hline Female gender, n (\%) & $150 / 582(26)$ & $77 / 240(32)$ & 0.07 \\
\hline Diabetes, n (\%) & $80 / 568(14)$ & $37 / 234(16)$ & 0.53 \\
\hline Hypertension, n (\%) & 199/529(38) & $101 / 229(44)$ & 0.09 \\
\hline Hyperlipidemia, n (\%) & $126 / 406(3 \mid)$ & $76 / 207(37)$ & 0.16 \\
\hline Smoking, n (\%) & $25 \mathrm{I} / 558(45)$ & $70 / 232(30)$ & $<0.001$ \\
\hline Previous MI, n (\%) & $81 / 578(14)$ & $45 / 233(19)$ & 0.06 \\
\hline
\end{tabular}

$\mathrm{MI}=$ myocardial infarction

STEMI. Mortality rate was 3/41 (7\%) vs. $2 / 20(10 \%), \mathrm{p}=$ 0.653, in the non-STEMI and STEMI patients who underwent $\mathrm{CABG}$.

Univariate predictors of mortality in the STEMI patients were age, diabetes, previous myocardial infarction, hypertension, previous myocardial infarction and no reperfusion (Table 4).

\section{Cox proportional hazard Analysis}

The following factors were included in the Cox-regression analysis: age, gender, diabetes, previous MI, hypertension, smoking, non-STEMI (STEMI reference) and no reperfusion therapy. This analysis revealed that age, diabetes, hypertension and no reperfusion therapy were significantly associated with increased risk of mortality (Table 5).

\section{Discussion}

This study identifies important differences in patient characteristics and management among patients discharged with the diagnosis of non-STEMI versus STEMI in a cohort of unselected patients. The higher mortality of patients with non-STEMI was due to differences in baseline characteristics and treatment.

The ratio of STEMI/non-STEMI is higher in our study as compared to other studies [7]. The is due the fact that, STEMI patients are consisted of those who are admitted primarily to our hospital, referred patients and those diagnosed by paramedics of the ambulance and transported directly to our centre for primary PCI. While, non-STEMI patients are consisted only of those admitted primarily to our hospital.

Our results are in accordance with a previous study [7], showing that non-STEMI patients have higher risk profiles and are treated less often with guideline recommended medication. The lower mortality rate in our study may be due to differences in treatment, rates of coronary angiography and revascularisation therapy were higher in our study. The prognosis after MI, for both non-STEMI and STEMI, in our study is worse as compared to two previous registries: the Euro Heart Survey of Acute Coronary Syndromes (EHS-ACS) and the Global Registry of Acute Coronary Events (GRACE) [8,9]. Possibly, in both GRACE

Table 2: Treatment and outcome

\begin{tabular}{|c|c|c|c|}
\hline & STEMI & non-STEMI & $P$-value \\
\hline CAG, $n(\%)$ & $540 / 583(93)$ & $|89 / 24|(78)$ & $<0.001$ \\
\hline \multicolumn{4}{|l|}{ Number of vessel disease } \\
\hline I, n (\%) & $242 / 540(45)$ & $65 / 189(34)$ & 0.025 \\
\hline$\geq 2, \mathrm{n}(\%)$ & $292 / 540(54)$ & $116 / 189(61)$ & \\
\hline No-CAD, n (\%) & $6 / 540(1)$ & $8 / 189(4)$ & \\
\hline Reperfusion & $510 / 583(87)$ & $|40 / 24|$ (58) & $<0.001$ \\
\hline $\mathrm{PCl}, \mathrm{n}(\%)$ & $481 / 583(83)$ & $99 / 24 I(4 I)$ & $<0.001$ \\
\hline Thrombolysis, n (\%) & $9 / 583(2.0)$ & - & \\
\hline CABG, n (\%) & $20 / 583(3)$ & $4 I / 24 I(I 7)$ & $<0.001$ \\
\hline Conservative, n (\%) & $73 / 583(13)$ & $101 / 241(42)$ & $<0.001$ \\
\hline Death, n (\%) & $71 / 574(12)$ & $47 / 236(20)$ & 0.006 \\
\hline
\end{tabular}

$\mathrm{CAG}=$ coronary angiography, $\mathrm{CAD}=$ coronary artery disease, $\mathrm{PCl}=$ percutaneous coronary intervention, $\mathrm{CABG}=$ coronary artery bypass grafting 
Table 3: Discharge medication

\begin{tabular}{llll}
\hline Medication & STEMI & non-STEMI & P-value \\
\hline Aspirin, $\mathrm{n}(\%)$ & $472 / 552(86)$ & $187 / 221(85)$ & 0.75 \\
Beta blocker, $\mathrm{n}(\%)$ & $484 / 553(88)$ & $188 / 221(85)$ & 0.36 \\
Clopidogrel, $\mathrm{n}(\%)$ & $91 / 227(40)$ & $<0.001$ \\
Statines, $\mathrm{n}(\%)$ & $381 / 553(69)$ & $126 / 221(57)$ & 0.052 \\
ACE-inhibitor, $\mathrm{n}(\%)$ & $356 / 552(65)$ & $87 / 221(39)$ & $<0.001$ \\
Nitrate, $\mathrm{n}(\%)$ & $300 / 553(54)$ & $65 / 221(29)$ & $<0.001$ \\
Calcium channel blocker $\mathrm{n}(\%)$ & $67 / 447(15)$ & $40 / 221(18)$ & $<0.001$
\end{tabular}

$\mathrm{ACE}=$ angiotensin converting enzyme

and EHS-ACS, some high-risk patients may have been excluded. For example, patients dying within $24 \mathrm{~h}$ of admission were excluded from GRACE.

Furthermore, compared to our study, many large scale randomized trials have reported lower mortality rates at one year follow up after MI [10-14]. The reason for this difference in outcome may due to low external validity of these trials due to numerous inclusion and exclusion criteria in these trials. Therefore, their results cannot be reasonably applied to patients in routine clinical practice [15]. Nevertheless, large scale clinical trials provide the most reliable data on the effects of treatment. Results of registries are suggested to be more externally valid than randomized trials because they include more high risk patients and are done in a real world setting $[16,17]$, however registries have also several limitations.

\section{Reasons for different outcomes}

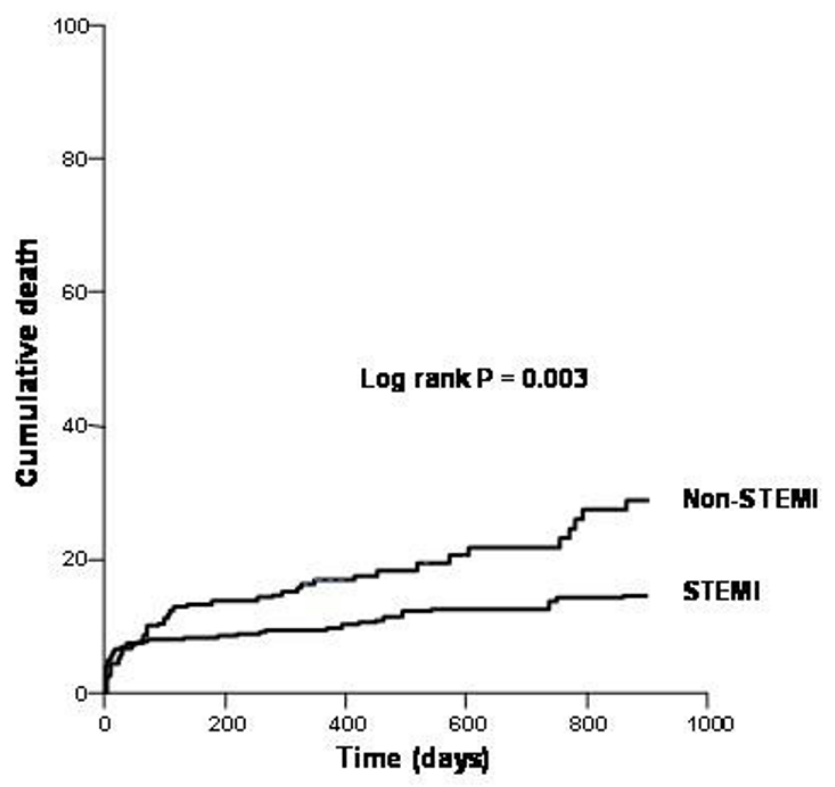

Figure I

Mortality curves stratified according to MI category.
The fact that non-STEMI patients were older, had higher risk profiles, were more often treated conservatively and less frequently received guideline recommended medication on the time of discharge, might possibly explain the difference in mortality rate. These results are in accordance with a previous study, showing that an early invasive management strategy is not utilized in many high-risk patients. An invasive strategy appears to be reserved for patients without significant co-morbidities and with a lower risk of in-hospital mortality [18]. However, in patients older than 75 years of age, a routine early invasive strategy may significantly improve clinical outcomes [19]. Finally, the fact that circumflex artery occlusions are more likely to present as non-STEMI than as STEMI might contribute to the worse outcome in non-STEMI patients [20].

\section{Challenges to improve outcome}

The outcomes in patients with acute coronary syndromes have improved over time. This was associated with the use of antiplatelet and antithrombotic therapies and the increased utilization of revascularization [21]. However, despite these improvements non-STEMI patients may have worse outcome [22]. Other factors than patient characteristics and treatment strategy that may account for worse outcome in non-STEMI are the fact that identification of MI is often delayed due to lack of definitive ECG abnormalities and timing of cardiac troponin elevation $[23,24]$. In addition, almost half of patients with nonSTEMI have other symptoms than chest pain when first seen, which may contribute to delayed diagnosis [25].

The question remains how we can further improve the outcome of patients with non-STEMI. This may be achieved by a multifactorial approach; first, identifying high risk patients, which can be done through a good clinical evaluation of medical history, physical examination, electrocardiogram (ECG) and cardiac biomarkers e.g. myoglobin, cardiac troponin and CK-MB $[26,27]$. Second, using the TIMI Risk Score, a simple clinical score that may be used by the clinician at the bedside for risk assessment and therapeutic decision-making, may improve patient management $[28,29]$. Third, an early invasive strategy may improve outcome. Several clinical trials have shown 
Table 4: Univariate analysis; predictors of mortality

\begin{tabular}{|c|c|c|c|c|c|c|}
\hline \multirow[b]{2}{*}{ Variable } & \multicolumn{3}{|c|}{ Non-STEMI } & \multicolumn{3}{|c|}{ STEMI } \\
\hline & $\overline{O R}$ & $95 \% \mathrm{Cl}$ & $\mathrm{P}$-value & $\overline{O R}$ & $95 \% \mathrm{Cl}$ & $P$-value \\
\hline Age per year & 1.14 & $1.09-1.20$ & $<0.001$ & 1.10 & $1.08-1.14$ & $<0.001$ \\
\hline Female gender & 0.85 & $0.43-1.68$ & 0.64 & 0.58 & $0.33-1.02$ & 0.06 \\
\hline Diabetes & 4.64 & $2.21-10.15$ & $<0.001$ & 3.6 & $1.93-6.72$ & $<0.001$ \\
\hline Previous MI & 4.42 & $2.12-9.21$ & $<0.001$ & 2.18 & I.5I-5.24 & 0.001 \\
\hline Hypertension & 1.03 & $0.53-2.02$ & 0.93 & 2.41 & $1.36-4.29$ & 0.003 \\
\hline Smoking & 0.58 & $0.26-1.30$ & 0.19 & 0.39 & $0.21-0.74$ & 0.004 \\
\hline No reperfusion & 8.34 & $3.70-18.70$ & $<0.001$ & 4.4 & $2.60-7.60$ & $<0.001$ \\
\hline
\end{tabular}

$\mathrm{MI}=$ myocardial infarction

the beneficial effect of this strategy, and this may be even grater when combined with early initiation of glycoprotein IIb/IIIa inhibitors [18,22,30-32]. Finally, recent data from the CRUSADE (Can Rapid risk stratification of Unstable angina patients Suppress ADverse outcomes with Early implementation of the ACC/AHA guidelines) demonstrated that guideline recommended medication is underused despite their proven clinical benefit [33]. Treating patients according to the current guidelines $[1,5]$ will improve prognosis after MI, as has been reported in recent studies [34-36].

\section{Future trials}

All the above mentioned trials have increased our knowledge with regard to how we should treat high-risk patients with non-STEMI. However, very early aggressive therapy in non-STEMI patients, as is performed in STEMI, remains a field for further research. Further studies are warranted to evaluate whether immediate cardiac catheterization and reperfusion in high-risk non-STEMI patients will further improve the outcome.

\section{Limitations}

Although we tried to register all patients with AMI, it is however, not possible to include all patients e.g. STEMI patients that are not referred for atypical chest pain or are presented too late. However, when comparing only patients admitted directly to our hospital, results remained unchanged. Other factors such as co-morbidity or contraindications for each considered treatment may account for differences in outcome. Thus selection bias may play a role in our study. Other factors such as history of stroke, neoplasm and depression mat affect both treatment and outcome, however, we have no data regarding these variables. Furthermore, we have no separate date on bundle branch block MI (BBBMI), as they seem to have worse outcome [7]. However in the presence of left BBBMI, the Wellens criteria [37] were used to determine whether a patient has STEMI or non-STEMI. Finally, this study reports the treatment and outcome in AMI patients discharged in 2001 and it may not fully reflect current care. By that time the available national guidelines already recommended intensive antithrombotic agents.

\section{Conclusion}

This study shows important differences in baseline characteristics, treatment and prognosis between non-STEMI and STEMI patients. A more invasive therapy and guideline recommended treatment might further improve outcome, especially in the non-STEMI population.

\section{Competing interests}

The author(s) declare that they have no competing interests.

Table 5: Hazard ratios of mortality of the significant factors in the multivariate model

\begin{tabular}{llll}
\hline Variable & HR & $95 \% \mathrm{Cl}$ & $P$-value \\
\hline Age, per year & 1.06 & $1.02-1.10$ & 0.002 \\
Female gender & 1.01 & $0.63-1.90$ & 0.75 \\
Diabetes & 1.78 & $1.01-3.17$ & 0.04 \\
Previous MI & 1.74 & $0.98-3.09$ & 0.06 \\
Hypertension & 171 & $1.01-2.88$ & 0.04 \\
Smoking & 1.49 & $0.75-2.94$ & 0.25 \\
MVD & 1.68 & $0.71-4.0$ & 0.24 \\
Non-STEMF & 1.11 & $0.64-1.93$ & 0.71 \\
No reperfusion & 2.95 & $1.64-5.29$ & $<0.001$ \\
\hline
\end{tabular}

$M I=$ myocardial infarction, $M V D=$ multi vessel disease, $*$ STEMI is reference group, Reperfusion (PCl or CABG). 


\section{Authors' contributions}

SR: participated in the design of the study, performed statistical analyses and drafted the manuscript. JPO participated in the study design and coordination and helped draft the manuscript. J-HD, M-JB, JH, MG, FZ and HS participated in the design of the study helped draft the manuscript. $\mathrm{AH}$ is the principle investigator, has made substantial contributions to conception and design of the study. All authors read and approved the final manuscript.

\section{References}

I. Van de Werf F, Ardissino D, Betriu A, Cokkinos DV, Falk E, Fox KA, Julian D, Lengyel M, Neumann FJ, Ruzyllo W, Thygesen C, Underwood SR, Vahanian A, Verheugt FW, Wijns W, Task Force on the Management of Acute Myocardial Infarction of the European Society of Cardiology: Management of acute myocardial infarction in patientspresenting with ST-segment elevation. Eur Heart J 2003, 24:28-66.

2. Boersma E, Maas AC, Deckers JW, Simoons ML: Early thrombolytic treatment in acute myocardial infarction: reappraisal of the golden hour. Lancet 1996, 348:771-775.

3. Fibrinolytic Therapy Trialists' (FTT) Collaborative Group: Indications for fibrinolytic therapy in suspected acute myocardial infarction: collaborative overview of early mortality and morbidity resultsfrom all randomised trials of more than I 000 patients. Lancet 1994, 343:3 II-322.

4. Keeley EC, Boura JA, Grines CL: Primary angioplasty versus intravenous thrombolytic therapy for acute myocardial infarction: a quantitative review of $\mathbf{2 3}$ randomised trials. Lancet 2003, 36 I: I3-20.

5. Braunwald E, Antman EM, Beasley JW, Califf RM, Cheitlin MD, Hochman JS, Jones RH, Kereiakes D, Kupersmith J, Levin TN, Pepine CJ, Schaeffer JW, Smith EE 3rd, Steward DE, Theroux P, Gibbons RJ, Alpert JS, Faxon DP, Fuster V, Gregoratos G, Hiratzka LF, Jacobs AK, Smith SC Jr, American College of Cardiology; American Heart Association: ACC/AHA guideline update for the management of patients with unstable angina and non-ST-segment elevation myocardial infarction-2002: summary article: a report of the American College of Cardiology/American Heart Association Task Force on Practice Guidelines (Committee on the Management of Patients with Unstable Angina). Circulation 2002, I06: 1893-1900.

6. Braunwald E: Application of current guidelines to the management of unstable angina and non-ST-elevation myocardial infarction. Circulation 2003, 108:28-37.

7. Terkelsen CJ, Lassen JF, Norgaard BL, Gerdes JC, Jensen T, Gotzsche LB, Nielsen TT, Andersen HR: Mortality rates in patients with ST-elevation vs. non-ST-elevation acute myocardial infarction: observations from an unselected cohort. Eur Heart J 2005, 26: 18-26.

8. Hasdai D, Behar S, Wallentin L, Gitt AK, Boersma E, Fioretti PM, Simoons ML, Battler A: A prospective survey of the characteristics, treatments and outcomes of patients with acute coronary syndromes in Europe and the Mediterranean basin; the Euro Heart Survey of Acute Coronary Syndromes (Euro Heart Survey ACS). Eur Heart J 2002, 23: I I 90-1201.

9. Goldberg RJ, Currie K, White K, Brieger D, Steg PG, Goodman SG, Dabbous O, Fox KA, Gore JM: Six-month outcomes in a multinational registry of patients hospitalized with an acute coronary syndrome (the Global Registry of Acute Coronary Events [GRACE]). Am J Cardiol 2004, 93:288-293.

10. Andersen HR, Nielsen TT, Rasmussen, Thuesen L, Kelbaek H, Thayssen P, Abildgaard U, Pedersen F, Madsen JK, Grande P, Villadsen AB, Krusell LR, Haghfelt T, Lomholt P, Husted SE, Vigholt E, Kjaergard HK, Mortensen LS, DANAMI-2 Investigators: A Comparison of coronary angioplasty with fibrinolytic therapy in acute myocardial infarction. N Engl J Med 2003, 349:733-742.

II. The GUSTO V Investigators: Reperfusion therapy for acute myocardial infarction with fibrinolytic therapy or combination reduced fibrinolytic therapy and platelet glycoprotein Ilb/IIla inhibition: the GUSTO V randomised trial. Lancet 2001, 357:1905-1914.
12. Assessment of the Safety and Efficacy of a New Thrombolytic (ASSENT-2) Investigators: Single-bolus tenecteplase compared with front-loadedalteplase in acute myocardial infarction: the ASSENT-2 double blind randomised trial. Lancet 1999, 354:716-722

13. Sinnaeve P, Alexander J, Belmans A, Bogaerts K, Langer A, Diaz R, Ardissino D, Vahanian A, Pehrsson K, Armstrong P, Van de Werf F, ASSENT-2 Investigators: One-year follow-up of the ASSENT-2 trial: a double-blind, randomized comparison of single-bolus tenecteplase and front-loaded alteplase in 16,949 patients with ST-elevation acutemyocardial infarction. Am Heart J 2003, 146:27-32.

14. Lincoff AM, Califf RM, Van de WF, Willerson JT, White HD, Armstrong PW, Guetta V, Gibler WB, Hochman JS, Bode C, Vahanian A, Steg PG, Ardissino D, Savonitto S, Bar F, Sadowski Z, Betriu A, Booth JE, Wolski K, Waller M, Topol EJ, Global Use of Strategies To Open Coronary Arteries Investigators (GUSTO): Mortality at I year with combination platelet glycoprotein IIb/IIla inhibition and reduced-dose fibrinolytic therapy vs conventional fibrinolytic therapy for acute myocardial infarction: GUSTO $V$ randomized trial. JAMA 2002, 288:2 I30-2I35.

15. Rothwell PM: External validity of randomised controlled trials: To whom do the results of this trial apply?". Lancet 2005, 365:82-93.

16. Black N: Why we need observational studies to evaluate the effectiveness of health care. BMJ 1996, 3 I 2:1215-1218.

17. McKee M, Britton A, Black N, McPherson K, Sanderson C, Bain C: Methods in health service research. Interpreting the evidence: choosing between randomised and non-randomised studies. BMJ 1999, 319:312-315.

18. Bach RG, Cannon CP, Weintraub WS, DiBattiste PM, Demopoulos LA, Anderson HV, DeLucca PT, Mahoney EM, Murphy SA, Braunwald $\mathrm{E}$ : Early cardiac catheterization is associated with lower mortality only among high-risk patients with ST- and non-ST-elevation acute coronary syndromes: Observations from the OPUS-TIMI I 6 trial. Ann Intern Med 2004, I 4 I: | 86- I 95.

19. de Boer MJ, Ottervanger JP, van 't Hof AWJ, Hoorntje JCA, Suryapranata H, Zijlstra F, Zwolle Myocardial Infarction Study Group: Reperfusion therapy in elderly patients with acute myocardial infarction: a randomized comparison of primary angioplasty and thrombolytic therapy. J Am Coll Cardiol 2002, 39:I723-I728.

20. Abbas AE, Boura JA, Brewington SD, Dixon SR, O'Neill WW, Grines $C L$ : Acute angiographic analysis of non ST segment elevation acute myocardial infarction. Am J Cardiol 2004, 94:907-909.

21. Almeda FQ, Hendel RC, Nathan S, Meyer PM, Calvin JE, Klein LW: Improved in-hospital outcomes in acute coronary syndromes(unstable angina/non-ST segment elevation myocardial infarction) despite similar TIMI risk scores. J Invasive Cardiol 2003, I 5:502-506.

22. Niemela K, Vikman S: Early invasive therapy of non ST-elevation acute coronary syndromes - combined with upstream antiplatelet therapy: yes - but how early? Eur Heart J 2003, 24:1383-1384.

23. Newby LK, Alpert JS, Ohman EM, Thygesen K, Califf RM: Changing the diagnosis of acute myocardial infarction: implicationsfor practice and clinical investigations. Am Heart J 2002, 144:957-980.

24. Alpert JS, Thygesen K, Antman E, Bassand JP: Myocardial infarction redefined - a consensus document of The Joint European Society ofCardiology/American College of Cardiology Committee for the redefinition ofmyocardial infarction. J Am Coll Cardiol 2000, 36:959-969.

25. Roe MT, Parsons LS, Pollack CV Jr, Canto JG, Barron HV, Every NR, Rogers WJ, Peterson ED, National Registry of Myocardial Infarction Investigators: Quality of care by classification of myocardial infarction: treatment patterns for ST-segment elevation vs non-ST-segment elevation myocardial infarction. Arch Intern Med 2005, 165:1630-1636.

26. Escabi-Mendoza J, Rosales-Alvarez C: Risk stratification in the patient with non ST segment elevation acute coronary syndrome. PR Health Sci J 2005, 24:323-336.

27. Kleiman NS, Lakkis N, Cannon CP, Murphy SA, DiBattiste PM, Demopoulos LA, Weintraub WS, Braunwald E, TACTICS-TIMI I Investigators: Prospective analysis of creatine kinase muscle-brain fraction and comparison with troponin $T$ to predict cardiac risk and benefit of an invasive strategy in patients with non- 
ST-elevation acute coronary syndromes. J Am Coll Cardiol 2002, 40:1044-1050.

28. Antman EM, Cohen M, Bernink PJ, McCabe CH, Horacek T, Papuchis G, Mautner B, Corbalan R, Radley D, Braunwald E: The TIMI risk score for unstable angina/non-ST elevation MI: A method for prognostication and therapeutic decision making. JAMA 2000, 284:835-842.

29. Maseri A, Rebuzzi AG, Cianflone D: Need for a composite risk stratification of patients with unstable coronary syndromes tailored to clinical practice. Circulation 1997, 96:4|4|-4I42.

30. Mega JL, Morrow DA, Sabatine MS, Zhao XQ, Snapinn SM, DiBattiste PM, Gibson CM, Antman EM, Braunwald E, Theroux P: Correlation between the TIMI risk score and high-risk angiographic findings in non-ST-elevation acute coronary syndromes: Observations from the Platelet Receptor Inhibition in Ischemic Syndrome Management in Patients Limited by Unstable Signs and Symptoms (PRISM-PLUS) trial. Am Heart J 2005, | 49:846-850.

31. Cannon CP, Weintraub WS, Demopoulos LA, Vicari R, Frey MJ, Lakkis N, Neumann FJ, Robertson DH, DeLucca PT, DiBattiste PM, Gibson CM, Braunwald E, TACTICS-TIMI 18 Investigators: Comparison of early invasive and conservative strategies in patients with unstable coronary syndromes treated with the glycoprotein Ilb/llla inhibitor tirofiban. N Engl J Med 200I, 344: $1879-1887$.

32. Morrow DA, Cannon CP, Rifai N, Frey MJ, Vicari R, Lakkis N, Robertson DH, Hille DA, DeLucca PT, DiBattiste PM, Demopoulos LA, Weintraub WS, Braunwald E, TACTICS-TIMI I8 Investigators: Ability of minor elevations of troponins $I$ and $T$ to predict benefit from a early invasive strategy in patients with unstable angina and non-ST elevation myocardial infarction: results from a randomized trial. JAMA 200I, 286:2405-24I2.

33. Roe MT, Ohman EM, Pollack CV Jr, Peterson ED, Brindis RG, Harrington RA, Christenson RH, Smith SC Jr, Califf RM, Gibler WB: Changing the model of care for patients with acute coronary syndromes. Am Heart J 2003, I46:605-6II.

34. Rasoul S, Ottervanger JP, de Boer MJ, Miedema K, Hoorntje JCA, Gosselink ATM, Zijlstra F, Suryapranata H, Dambrink JHE, van 't Hof AW]: A comparison of dual versus triple antiplatelet therapyin patients with non ST segment elevation acute coronary syndromes. Results of the ELISA-2 trial. Eur Heart J 2006, 27:|140|-|407.

35. Kastrati A, Mehilli J, Neumann FJ, Dotzer F, ten Berg J, Bollwein H, Graf I, Ibrahim M, Pache J, Seyfarth M, Schuhlen H, Dirschinger J, Berger PB, Schomig A, Intracoronary Stenting and Antithrombotic: Regimen Rapid Early Action for Coronary Treatment 2 (ISAR-REACT 2) Trial Investigators: Abciximab in Patients With Acute Coronary Syndromes Undergoing Percutaneous Coronary Intervention After Clopidogrel Pretreatment: The ISAR-REACT 2 Randomized Trial. JAMA 2006, 295: I53|-1538.

36. Mehta RH, Montoye CK, Gallogly M, Baker P, Blount A, Faul J, Roychoudhury C, Borzak S, Fox S, Franklin M, Freundl M, Kline-Rogers E, LaLonde T, Orza M, Parrish R, Satwicz M, Smith MJ, Sobotka P, Winston S, Riba AA, Eagle KA, GAP Steering Committee of the American College of Cardiology: Improving quality of care for acute myocardial infarction: The Guidelines Applied in Practice (GAP) Initiative. JAMA 2002, 287:1269-1276.

37. Wellens HJ: Acute myocardial infarction and left bundlebranch block - can we lift the veil? N Engl J Med 1996, 334:528-529.

\section{Pre-publication history}

The pre-publication history for this paper can be accessed here:

http://www.biomedcentral.com/1471-2261/7/8/prepub
Publish with Biomed Central and every scientist can read your work free of charge

"BioMed Central will be the most significant development for disseminating the results of biomedical research in our lifetime. "

Sir Paul Nurse, Cancer Research UK

Your research papers will be:

- available free of charge to the entire biomedical community

- peer reviewed and published immediately upon acceptance

- cited in PubMed and archived on PubMed Central

- yours - you keep the copyright

Submit your manuscript here:

http://www.biomedcentral.com/info/publishing_adv.asp
BioMedcentral 